\section{Indaziflam Programs for Weed Control in Overseeded Bermudagrass Turf}

\author{
Gerald M. Henry ${ }^{1,4}$, James T. Brosnan², Greg K. Breeden², \\ Tyler Cooper ${ }^{3}$, Leslie L. Beck ${ }^{3}$, and Chase M. Straw ${ }^{1}$
}

ADDITIONAL INDEX WORDS. annual bluegrass, golf course, perennial ryegrass, turfgrass

SumMARY. Indaziflam is an alkylazine herbicide that controls winter and summer annual weeds in bermudagrass (Cynodon sp.) turf by inhibiting cellulose biosynthesis. Research was conducted in Tennessee and Texas during 2010 and 2011 to evaluate the effects of indaziflam applications on overseeded perennial ryegrass (Lolium perenne) establishment and summer annual weed control. In Texas, perennial ryegrass cover on plots treated with indaziflam at 0.75 and $1.0 \mathrm{oz} /$ acre measured $37 \%$ to $48 \%$ compared with $88 \%$ for the untreated control 257 days after initial treatment (DAIT). Perennial ryegrass cover following applications of indaziflam at $0.5 \mathrm{oz} /$ acre measured $84 \% 257$ DAIT and did not differ from the untreated control on any evaluation date. Inconsistent responses in crabgrass (Digitaria sp.) control with indaziflam at $0.5 \mathrm{oz} /$ acre were observed in Tennessee and Texas. However, control was similar to the $0.75-\mathrm{oz} /$ acre rate and prodiamine at $7.8 \mathrm{oz} /$ acre at each location. A September application of indaziflam at $0.75 \mathrm{oz} /$ acre followed by a sequential treatment at $0.5 \mathrm{oz} /$ acre in March of the following year provided $>90 \%$ control by June 2011 . Indaziflam application regimes of this nature would allow for successful fall overseeding of perennial ryegrass every two years and control winter annual weed species such as annual bluegrass (Poa annua).

$\mathrm{B}$ ermudagrass golf course fairways and athletic fields are commonly overseeded with a cool-season turfgrass, like perennial ryegrass, to provide green cover and improve aesthetic quality during winter months (Horgan and Yelverton, 2001). Thoms et al. (2011) reported that overseeding 'Tifway 419' hybrid bermudagrass (Cynodon dactylon $\times C$. transvaalensis) not only increased green cover under simulated traffic, but hypothesized that overseeding protected dormant bermudagrass from traffic stress. Fall overseeding is a common practice on golf courses and athletic fields in the southern United States. Perennial ryegrass may persist in bermudagrass turf for three to nine

The authors thank Joe Hope, John Rowland, and the Tennessee Agricultural Experiment Station for their assistance in this research.

Mention of trade names or commercial products in this publication is solely for the purpose of providing specific information and does not imply recommendation or endorsement by the University of Tennessee Institute of Agriculture.

${ }^{1}$ Department of Crop and Soil Sciences, University of Georgia, 3111 Miller Plant Sciences Building, Athens, GA 30602

${ }^{2}$ Department of Plant Sciences, University of Tennessee, 2431 Joe Johnson Dr., Knoxville, TN 37996

${ }^{3}$ Department of Plant and Soil Science, Texas Tech University, Box 42122, Lubbock, TX 79409

${ }^{4}$ Corresponding author. E-mail: gmhenry@uga.edu. months depending on geographic location (Mazur, 1984).

Applications of preemergence (PRE) herbicides for summer annual weed control can compromise establishment of overseeded cool-season turfgrass species in the fall. Yelverton and McCarty (2001) reported that prodiamine reduced perennial ryegrass establishment when applied at $430 \mathrm{~g} \cdot \mathrm{ha}^{-1} 6$ weeks before overseeding. The researchers also demonstrated that increasing the prodiamine rate to $560 \mathrm{~g} \cdot \mathrm{ha}^{-1}$ extended the interval required for successful perennial ryegrass establishment to 8 weeks. Similarly, Keeley and Zhou (2005) reported that prodiamine at $840 \mathrm{~g} \cdot \mathrm{ha}^{-1}$ reduced kentucky bluegrass (Poa pratensis) establishment unless broadcast seeding was delayed for 14 weeks after herbicide treatment. This interval increased to 16 weeks when seeding was performed with slit-seeding techniques often used for overseeding bermudagrass turf.

Indaziflam is an alkylazine herbicide that controls winter and summer annual weeds in bermudagrass turf by inhibiting cellulose biosynthesis (Myers et al., 2009). Brosnan et al. (2011) reported that PRE applications of indaziflam at 35 to $70 \mathrm{~g} \cdot \mathrm{ha}^{-1}$ controlled smooth crabgrass (Digitaria ischaemum) similar to prodiamine at $840 \mathrm{~g} \cdot \mathrm{ha}^{-1}$. Further studies illustrated that indaziflam provides effective postemergence control of nontillering smooth crabgrass plants at $35 \mathrm{~g} \cdot \mathrm{ha}^{-1}$ (Brosnan and Breeden, 2012). Current labeling restricts perennial ryegrass overseeding following indaziflam applications. Perennial ryegrass overseeding must be delayed a minimum of eight months following treatment at $35 \mathrm{~g} \cdot \mathrm{ha}^{-1}$ and 12 months at rates greater than $53 \mathrm{~g} \cdot \mathrm{ha}^{-1}$. Overseeding restrictions of this nature may limit indaziflam use by turf managers.

Sequential application programs could provide turf managers with effective summer annual weed control without compromising perennial ryegrass establishment. Perry et al. (2011) reported that indaziflam (20 to 60 $\mathrm{g} \cdot \mathrm{ha}^{-1}$ ) programs involving fall $(\mathrm{Oc}-$ tober and November) and spring (March and April) applications controlled large crabgrass (Digitaria sanguinalis) $>90 \%$ in June. These regimes may allow for successful establishment of overseeded perennial ryegrass in late fall. However, Perry et al. (2011) did not evaluate perennial ryegrass establishment.

Data describing effects of single and sequential indaziflam applications on overseeded perennial ryegrass establishment and summer annual weed control are limited. Considering the prevalence of dinitroaniline-resistant annual grassy weeds in the southern United States (Cutulle et al., 2009; Isgrigg III et al., 2002; Mudge et al., 1984; Vaughn et al., 1990), providing

\begin{tabular}{llll}
\hline $\begin{array}{l}\text { Units } \\
\text { To convert U.S. to SI, } \\
\text { multiply by }\end{array}$ & U.S. unit & SI unit & $\begin{array}{l}\text { To convert SI to U.S., } \\
\text { multiply by }\end{array}$ \\
\hline 0.3048 & $\mathrm{ft}$ & $\mathrm{m}$ & 3.2808 \\
9.3540 & gal/acre & $\mathrm{L} \cdot \mathrm{ha}^{-1}$ & 0.1069 \\
2.54 & inch $(\mathrm{es})$ & $\mathrm{cm}$ & 0.3937 \\
48.8243 & lb/l000 $\mathrm{ft}^{2}$ & $\mathrm{~kg} \cdot \mathrm{ha}^{-1}$ & 0.0205 \\
1.1209 & $\mathrm{lb} / \mathrm{acre}$ & $\mathrm{kg} \cdot \mathrm{ha}^{-1}$ & 0.8922 \\
70.0532 & $\mathrm{oz} / \mathrm{acre}$ & $\mathrm{g} \cdot \mathrm{ha}^{-1}$ & 0.0143 \\
$\left({ }^{\circ} \mathrm{F}-32\right) \div 1.8$ & ${ }^{\circ} \mathrm{F}$ & ${ }^{\circ} \mathrm{C}$ & $\left({ }^{\circ} \mathrm{C} \times 1.8\right)+32$
\end{tabular}


turf managers with a new mode of action may be beneficial for resistance management. Therefore, the objectives of this research were to evaluate the effects of indaziflam applications on perennial ryegrass establishment and summer annual weed control.

\section{Materials and methods}

OVERSEEDED PERENNIAL RYEGRASS EXPERIMENTS. Research was conducted from Mar. to Nov. 2011 on a common bermudagrass golf course fairway at Reese Golf Course (Lubbock, TX) and a 'Tifway 419' hybrid bermudagrass fairway at Lake Ridge Country Club (Lubbock, TX). Soil at Reese Golf Course was a Mobeetie fine sandy loam (coarseloamy, mixed, superactive, thermic Aridic Haplustepts) with a $\mathrm{pH}$ of 7.8 and $1.2 \%$ organic matter. At Lake Ridge Country Club, the soil was a Brownfield sandy clay loam (loamy, mixed, superactive, thermic Arenic Aridic Paleustalfs) with a $\mathrm{pH}$ of 7.9 and $1.7 \%$ organic matter. To promote active bermudagrass growth, irrigation was applied every $2 \mathrm{~d}$ to deliver $\approx 2$ inches per week. Both sites were mowed at $\approx 0.25$ inch with clippings returned.

Treatments at each location included indaziflam (Specticle FLO; Bayer Environmental Sciences, Research Triangle Park, NC) at 0.5, 0.75 , and $1.0 \mathrm{oz} /$ acre; indaziflam at $0.75 \mathrm{oz} /$ acre followed by indaziflam at $0.5 \mathrm{oz} /$ acre; and prodiamine (Barricade 65WG; Syngenta Professional Products, Greensboro, NC) at 7.8 $\mathrm{oz} /$ acre. An untreated control was included for comparison. Treatments were applied to $5 \times 5$-ft plots with a carbon dioxide-powered boom sprayer calibrated to deliver $32.5 \mathrm{gal} / \mathrm{acre}$ using 8003 flat-fan spray nozzles (TeeJet; Spraying Systems, Wheaton, IL). Initial applications were made on 11 Mar. 2011 with treatments requiring a sequential application applied on 22 Apr. 2011. Soil temperature averaged $\approx 55{ }^{\circ} \mathrm{F}$ when treatments were applied at each location. The entire experimental area was overseeded with perennial ryegrass (Futura 2000 Perennial Ryegrass Blend; Pickseed, Lindsay, ON, Canada) at 349.4 lb/acre on 17 Oct. 2011. This date was 30 weeks after initial herbicide treatment. The research area was verticut (GS04 Verticutter; Graden USA, Richmond, VA) in two directions to a depth of 0.2 inch to open the canopy for overseeding without disturbing the soil profile. Perennial ryegrass seed was broadcast in two directions across the site using a cyclone spreader (Lesco 80-lb Rotary Broadcast Lawn Spreader; John Deere Landscapes, Troy, MI). A 10N-7.9P-14.9K starter fertilizer (Country Club 1018-18; Lebanon Turf, Lebanon, PA) was applied at $1 \mathrm{lb} / 1000 \mathrm{ft}^{2}$ nitrogen.

Perennial ryegrass cover was evaluated weekly during Nov. 2011. These dates corresponded to 235, 241, 248, and 257 DAIT. Data were collected using digital image analysis similar to Richardson et al. (2001). Digital images were captured using a $2 \times 2$-ft light box equipped with four compact florescent light bulbs [14Watt (60W) Daylight CFL Light Bulbs; N:Vision, Atlanta, GA) each with a light output of 800 lumens. Photographs were taken with a digital camera (Coolpix P5000; Nikon Inc. USA, Melville, NY) camera capable of capturing 10 million pixels per image. SigmaScan Pro software (version 5.0; Systat Software, San Jose, CA) converted image pixilation measurements to turfgrass cover according to the methods of Richardson et al. (2001) where pixels defined as green turf exhibited a hue range of $45^{\circ}$ to $120^{\circ}$ and saturation values between $0 \%$ and $100 \%$. Turfgrass cover was calculated by dividing the number of green turf pixels in each image by the total number of pixels in the image.

The experimental design at each location was a randomized complete block with four replications. Perennial ryegrass cover data were arcsine square-root transformed to stabilize variance (Ahrens et al., 1990) before being subjected to analysis of variance (ANOVA) in SAS (version 9.3; SAS Institute, Cary, NC), with main effects and all possible interactions tested using the appropriate expected mean square values described by McIntosh (1983). Interpretations were not different from nontransformed data; therefore, nontransformed means are presented for clarity. No significant location-by-treatment interactions were detected in perennial ryegrass cover data; thus, data from each location were combined. All data were subjected to ANOVA in SAS using the appropriate expected mean square values described by McIntosh (1983). Treatment means were separated using
Fisher's protected least significant difference (LSD) test at $\alpha=0.05$.

C R A B G R A S C O N T R O L EXPERIMENTS. Research was conducted from Sept. 2010 to July 2011 on a mature stand of 'Yukon' common bermudagrass at the University of Tennessee-Knoxville (TN) established on a Sequatchie loam soil (fine-loamy, siliceous, semiactive, thermic humic Hapludult) with a $\mathrm{pH}$ of 5.8 and organic matter content of $2.1 \%$. This experiment was replicated on a 'Tifway 419' hybrid bermudagrass fairway at Lake Ridge Country Club (Lubbock, TX). Soil at this location was a Brownfield sandy clay loam (loamy, mixed, superactive, thermic Arenic Aridic Paleustalfs) with a $\mathrm{pH}$ of 7.9 and $1.7 \%$ organic matter. Irrigation at each location was applied to promote active bermudagrass growth. Plots were mowed three times per week at $\approx 0.6$ inch in Tennessee and $\approx 0.25$ inch in Texas. Clippings were returned after mowing at each location. The Tennessee location had a history of smooth crabgrass infestation while the location in Texas had a history of large crabgrass infestation.

Treatments included indaziflam at 0.5 and $0.75 \mathrm{oz} / \mathrm{acre}$, indaziflam at 0.75 followed by $0.5 \mathrm{oz} / \mathrm{acre}$, and prodiamine at $7.8 \mathrm{oz} /$ acre. An untreated control was also included for comparison. Herbicides were applied using carbon dioxide-powered boom sprayers calibrated to deliver $30 \mathrm{gal} /$ acre in Tennessee and $32.5 \mathrm{gal} /$ acre in Texas. Sprayers in Tennessee and Texas had 8002 and 8003 flat-fan spray nozzles (TeeJet, Spraying Systems), respectively. Plot size in Tennessee measured $5 \times 10 \mathrm{ft}$ compared with $5 \times 5 \mathrm{ft}$ in Texas. Initial applications were made on 1 Sept. 2010 in Tennessee and 6 Sept. 2010 in Texas. Sequential treatments were applied on 2 Mar. 2011 in Tennessee and 1 Mar. 2011 in Texas. Bermudagrass phytotoxicity was visually assessed 1 and 2 weeks following each application on a percent scale relative to the untreated control, where 0 equaled no bermudagrass injury and 100 equaled complete bermudagrass death. Crabgrass control was visually assessed on a percent scale relative to the untreated control, where 0 equaled no crabgrass control and 100 equaled complete crabgrass control. Plots were evaluated in May and June at each location. 
The experimental design was a randomized complete block with three replications in Tennessee and four replications in Texas. Crabgrass control data were arcsine square-root transformed to stabilize variance (Ahrens et al., 1990) before being subjected to ANOVA in SAS, with main effects and all possible interactions tested using the appropriate expected mean square values described by McIntosh (1983). Interpretations were not different from nontransformed data; therefore, nontransformed means are presented for clarity. Significant location-by-treatment interactions were detected in crabgrass control data; thus, data from each location were analyzed and are presented separately. Treatment means were separated using Fisher's protected LSD test at the $\alpha=0.05$ level.

\section{Results and discussion}

OVERSEEDED PERENNIAL RYEGRASS EXPERIMENTS. Overseeded perennial ryegrass cover was affected by herbicide treatment (Table 1). Plots treated with indaziflam at 0.75 and $1.0 \mathrm{oz} /$ acre yielded $\leq 15 \%$ perennial ryegrass cover 241 DAIT compared with $72 \%$ for the untreated control. By 257 DAIT, perennial ryegrass cover on plots treated with indaziflam at 0.75 and $1.0 \mathrm{oz} /$ acre measured $37 \%$ to $48 \%$ compared with $88 \%$ for the untreated control. However, perennial ryegrass cover following applications of indaziflam at $0.5 \mathrm{oz} / \mathrm{acre}$ did not differ from the untreated control on any evaluation date. Perennial ryegrass cover following applications of indaziflam at $0.5 \mathrm{oz} / \mathrm{acre}$ measured $65 \%$ at 241 DAIT and $84 \%$ at 257 DAIT. Perennial ryegrass cover on plots treated with prodiamine at $7.8 \mathrm{oz} /$ acre did not differ from the untreated control on any evaluation date as well. This response supports the work of Yelverton and McCarty (2001) who reported that overseeding should occur at least 6 to 8 weeks following treatment with prodiamine at 430 and $560 \mathrm{~g} \cdot \mathrm{ha}^{-1}$ to avoid reductions in establishment. Overseeding was conducted 30 weeks after all herbicide treatments in the current study.

C R A B G R A S C C N T R O L EXPERIMENTS. No bermudagrass phytotoxicity was observed throughout the length of each trial regardless of herbicide treatment (data not shown).
Indaziflam application rates that allowed for successful establishment of overseeded perennial ryegrass $(0.5$ $\mathrm{oz} / \mathrm{acre}$ ) provided inconsistent crabgrass species control in this study (Table 2). Although indaziflam at $0.5 \mathrm{oz} /$ acre provided $100 \%$ control on both evaluation dates in Texas, this treatment only provided $85 \%$ control by May in Tennessee, which decreased to $67 \%$ by June. A similar response was observed with the $0.75-\mathrm{oz} /$ acre rate of indaziflam, as this treatment provided $100 \%$ control by June in Texas but only $72 \%$ control by June in Tennessee. Increasing indaziflam application rate from 0.5 to $0.75 \mathrm{oz} /$ acre did not increase control at either location, and both indaziflam treatments provided a similar level of control to prodiamine $(7.8 \mathrm{oz} /$ acre $)$ on each evaluation date. These responses support the finding of Brosnan et al. (2011).
Differential responses in control with indaziflam may be related to differences in crabgrass species density between locations (Table 2). Crabgrass species cover in untreated control plots measured $>40 \%$ on both dates in Tennessee compared with $<20 \%$ in Texas. Low crabgrass species density in Texas may be linked to the severe drought conditions experienced during 2011. The average Palmer drought severity index in Texas during Summer 2011 (June through August) was -5.37, indicating the most severe drought since 1895 (Dawson, 2011). Although plots in Texas were irrigated, high temperatures and low humidity during spring and summer months may have increased evaporative demand thus reducing large crabgrass germination and seedling plant vigor.

Applications of indaziflam in Sept. 2010 did not provide effective

Table 1. Fall perennial ryegrass overseeding cover in response to spring herbicide treatments applied at Reese Golf Course and Lake Ridge Country Club in Lubbock, TX, in 2011. Treatment means are combined from four replication experiments conducted at each location.

\begin{tabular}{|c|c|c|c|c|c|c|}
\hline \multirow[b]{2}{*}{ Herbicide } & \multirow[b]{2}{*}{$\begin{array}{c}\text { Rate } \\
(\mathrm{oz} / \text { acre })^{\mathrm{z}}\end{array}$} & \multirow[b]{2}{*}{ Date applied } & \multicolumn{4}{|c|}{ Perennial ryegrass cover $(\%)^{\mathrm{y}}$} \\
\hline & & & $\begin{array}{c}234 \\
\text { DAIT }^{\mathrm{x}} \\
\end{array}$ & $\begin{array}{c}241 \\
\text { DAIT }\end{array}$ & $\begin{array}{c}248 \\
\text { DAIT } \\
\end{array}$ & $\begin{array}{c}257 \\
\text { DAIT }\end{array}$ \\
\hline \multirow[t]{4}{*}{ Indaziflam } & 1.0 & 11 Mar. & 2 & 12 & 29 & 37 \\
\hline & 0.75 & 11 Mar. & 2 & 15 & 38 & 48 \\
\hline & 0.5 & 11 Mar. & 38 & 65 & 79 & 84 \\
\hline & $0.75+0.5$ & 11 Mar. + 22 Apr. & 1 & 8 & 23 & 31 \\
\hline Prodiamine & 7.8 & 11 Mar. & 43 & 69 & 81 & 88 \\
\hline Untreated control & - & - & 41 & 72 & 83 & 88 \\
\hline $\mathrm{LSD}_{0.05}{ }^{\mathrm{w}}$ & & & 5 & 8 & 8 & 7 \\
\hline
\end{tabular}

${ }^{\mathrm{z}} 1.0 \mathrm{oz} / \mathrm{acre}=70.0532 \mathrm{~g} \cdot \mathrm{ha}^{-1}$

y Perennial ryegrass was overseeded at $349.4 \mathrm{lb} /$ acre $\left(391.63 \mathrm{~kg} \cdot \mathrm{ha}^{-1}\right)$ on 17 Oct. $201 \mathrm{l}, 30$ weeks after herbicide application. Perennial ryegrass cover was assessed using digital image analysis similar to Richardson et al. (2001). ${ }^{x}$ Days after initial treatment.

weast significant difference at $P \leq 0.05$.

Table 2. Control of crabgrass species in response to preemergence herbicide treatments applied in Knoxville, TN, and Lubbock, TX, in 2010 and 2011.

\begin{tabular}{|c|c|c|c|c|c|c|}
\hline \multirow[b]{3}{*}{ Herbicide } & \multirow[b]{3}{*}{$\begin{array}{c}\text { Rate } \\
(\text { oz/acre })^{z}\end{array}$} & \multirow[b]{3}{*}{ Month applied ${ }^{y}$} & \multicolumn{4}{|c|}{ Crabgrass control (\%) } \\
\hline & & & \multicolumn{2}{|c|}{ Tennessee } & \multicolumn{2}{|c|}{ Texas } \\
\hline & & & $\begin{array}{l}\text { May } \\
2011\end{array}$ & $\begin{array}{l}\text { June } \\
2011\end{array}$ & $\begin{array}{l}\text { May } \\
2011\end{array}$ & $\begin{array}{l}\text { June } \\
2011\end{array}$ \\
\hline \multirow[t]{4}{*}{ Indaziflam } & 0.75 & Sept. 2010 & 37 & 17 & 21 & 6 \\
\hline & 0.75 & Mar. 2011 & 91 & 72 & 100 & 100 \\
\hline & 0.5 & Mar. 2011 & 85 & 67 & 100 & 100 \\
\hline & $0.75+0.5$ & Sept. $2010+$ Mar. 2011 & 97 & 90 & 100 & 100 \\
\hline Prodiamine & 7.8 & Mar. 2011 & 97 & 91 & 100 & 100 \\
\hline $\mathrm{LSD}_{0.05}{ }^{\mathrm{w}}$ & & & 25 & 28 & 22 & 20 \\
\hline
\end{tabular}

${ }^{\mathrm{z}} 1.0 \mathrm{oz} / \mathrm{acre}=70.0532 \mathrm{~g} \cdot \mathrm{ha}^{-1}$.

yTreatments were applied on 1 Sept. 2010 and 2 Mar. 2011 in Tennessee and 6 Sept. 2010 and 1 Mar. 2011 in Texas.

xPlots in Tennessee and Texas were infested with smooth crabgrass and large crabgrass, respectively. Crabgrass cover in untreated control plots measured $>40 \%$ on both dates in Tennessee compared with $<20 \%$ in Texas. Control at each location was visually assessed on a percent scale relative to an untreated control, where 0 equaled no control and 100 equaled complete control. Assessments were made during May and June 2011 at each location.

weast significant difference at $P \leq 0.05$. 
crabgrass species control during the Summer 2011 (Table 2). By June 2011 , control measured only $17 \%$ in Tennessee and $6 \%$ in Texas. However, effective control was achieved when a fall application at $0.75 \mathrm{oz} /$ acre was followed by a March application at $0.5 \mathrm{oz} / \mathrm{acre}$. This treatment provided $>90 \%$ crabgrass species control on every evaluation date at each location. These responses are similar to those reported by Perry et al. (2011) who found October applications of indaziflam controlled large crabgrass $\leq 24 \%$ in June of the following year. However, when October applications of indaziflam (20 to $60 \mathrm{~g} \cdot \mathrm{ha}^{-1}$ ) were followed by a sequential application in March, Perry et al. (2011) observed $>95 \%$ large crabgrass control.

Current indaziflam labeling restricts overseeding for 32 weeks after treatment at $0.5 \mathrm{oz} /$ acre. Results of this research suggest that spring applications of indaziflam at $0.5 \mathrm{oz} / \mathrm{acre}$ do not affect overseeded perennial ryegrass establishment 30 weeks after herbicide treatment. However, crabgrass species control with indaziflam at $0.5 \mathrm{oz} /$ acre may be variable. When a September application of indaziflam at $0.75 \mathrm{oz} /$ acre was followed by a sequential treatment in March of the following year at $0.5 \mathrm{oz} / \mathrm{acre}$, crabgrass species control exceeded $90 \%$ on all evaluation dates. A program of this nature would allow for successful fall overseeding every two years. In addition, this program would control winter annual weed species including annual bluegrass and various broadleaf species (Brosnan et al., 2012; Perry et al., 2011).

\section{Literature cited}

Ahrens, W.H., D.J. Cox, and G. Budhwar. 1990. Use of the arcsine and square root transformations for subjectively determined percentage data. Weed Sci. 38: $452-458$.

Brosnan, J.T. and G.K. Breeden. 2012. Application placement affects postemergence smooth crabgrass and annual bluegrass control with indaziflam. Weed Technol. (In press).

Brosnan, J.T., G.K. Breeden, P.E. McCullough, and G.M. Henry. 2012. Pre- and postemergence annual bluegrass control with indaziflam. Weed Technol. $26: 48-53$

Brosnan, J.T., P.E. McCullough, and G.K. Breeden. 2011. Smooth crabgrass control with indaziflam at various spring timings. Weed Technol. 25:363-366.

Cutulle, M.A., J.S. McElroy, R.W. Millwood, J.C. Sorochan, and C.N. Stewart. 2009. Selection of bioassay method influences detection of annual bluegrass resistance to mitotic-inhibiting herbicides. Crop Sci. 49:1088-1095

Dawson, B. 2011. A drought for the centuries: It hasn't been this dry in Texas since 1789. 19 Dec. 2011 . <http://texasclimatenews.org $/ \mathrm{wp} / \mathrm{p} \mathrm{p}=3355>$.

Horgan, B.P. and F.H. Yelverton. 2001 Removal of perennial ryegrass from overseeded bermudagrass using cultural methods. Crop Sci. 41:118-126.

Isgrigg, J., III, F.H. Yelverton, C. Brownie, and L.S. Warren. 2002. Dinitroaniline resistant annual bluegrass in North Carolina. Weed Sci. 50:86-90.

Keeley, S.J. and H. Zhou. 2005. Preemergence herbicide and seeding methods effects on seedling growth of kentucky bluegrass. Weed Technol. 19:43-46.
Mazur, A.R. 1984. Chemical aids during winter overseeding. Carolinas Nwsl. 20(2):20-26.

McIntosh, M.S. 1983. Analysis of combined experiments. Agron. J. 75:153-155.

Mudge, L.C., B.J. Gossett, and T.R. Murphy. 1984. Resistance of goosegrass (Eleusine indica) to dinitroaniline herbicides. Weed Sci. 32:591-594.

Myers, D.F., R. Hanrahan, J. Michel, B. Monke, L. Mudge, C. Olsen, A. Parker, J. Smith, and D. Spak. 2009. Indaziflam/ BCS AA170717: A new herbicide for preemergent control of grasses and broadleaves in turf and ornamentals. Proc. Southern Weed. Sci. Soc. 62:393.

Perry, D.H., J.S. McElroy, M.C. Doroh, and R.H. Walker. 2011. Indaziflam utilization for controlling problematic turfgrass weeds. Online. Appl. Turfgrass Sci. doi:10.1094/ATS-2011-0428-01-RS.

Richardson, M.D., D.E. Karcher, and L.C. Purcell. 2001. Quantifying turfgrass cover using digital image analysis. Crop Sci. 41:1884-1888.

Thoms, A.W., J.C. Sorochan, J.T. Brosnan, and T.J. Samples. 2011. Perennial ryegrass (Lolium perenne L.) and grooming affect bermudagrass traffic tolerance. Crop Sci. 51:2204-2211.

Vaughn, K.C., M.A. Vaughn, and B.J. Gossett. 1990. A biotype of goosegrass (Eleusine indica) with an intermediate level of dinitroaniline herbicide resistance. Weed Technol. 4:157-162.

Yelverton, F.H. and L.B. McCarty. 2001. Tolerance of perennial ryegrass and $P o a$ annua control with herbicides in overseeded bermudagrass. Intl. Turfgrass Soc. Res. J. 9:1050-1055. 